\title{
Problemas genológicos del discurso ensayístico: O rigen y configuración de un género
}

Claudio Maiz

CONICET-Universidad Nacional de Cuyo

\begin{abstract}
Resumen
El propósito de este trabajo consiste en desplegar ciertos argumentos que faciliten la tarea de esclarecer el problema genológico y el valor literario del ensayo. Para ello hemos recurrido a una distinción entre las poéticas esencialistas y condicionalistas. Estas últimas han resultado de mayor efectividad, en razón de que se ajustan mejor al examen de un género de la modernidad renacentista, no previsto por la poética clásica. Las poéticas condicionalistas plantean la propiedad literaria de los textos en relación con los niveles contextuales y no cotextuales. La estrucutura argumentativa del ensayo constituye la bisagra que reúne el ordenamiento más o menos sistemático del pensamiento, por lo que se acerca al discurso teorético, pero la preocupación por la 'dispositio' y la 'elocutio' delas estructuraciones retóricas, lo proyecta hacia una noción artística.
\end{abstract}

Palabras Claves: Teoría literaria, poética, retórica, discursos ensayísticos.

\section{Abstract}

The purpose of this work consists of unfolding certain arguments that facilitate the task of clarifying the gender issues and the literary value of the essay. For it we have resorted to a distinction between the essential theory and the conditional poetics. The latter has been of great effectiveness for they adjust better to the examination of a literary gender of Renaissance modernity, not anticipated by the classical poetic. The conditional poetics raise the literary property of texts in relation with the contextual and non co-textual levels. The argumentative structure of the essay constitutes the hinge that assembles the more or less systematic order of thought, reason why it approaches the theoretical discourse, but the preoccupation about the "dispositio" and the "elocutio" of therhetorical structures projects it towards an artistic notion.

KEYWoRds: Literary theory, poetics, rhetoric, essay discourses.

Recibido: 06.12.2002. Aceptado: 09.12.2002. 


\section{EL ENFOQUE GENOLOGICO}

S NOTABLE que el ensayo, un género discursivo tan frecuentado, no cuente proporcionalmente con más estudios de profundo valor científico. 0 bviamente, no faltan trabajos que intentan penetrar con rigor los caracteres formales de este discurso, aunque en la mayoría de los casos son breves pero de pretensión panorámica o bien, simplemente, circunscriptos a aspectos muy específicos. Tampoco faltan, en el arborescente conjunto de estudios y tratados, las antologías, que parecieran constituir una tentación para los quefrecuentan el asunto, organizadas por temas, cronologías o, lisa y llanamente, a partir de las preferencias del antólogo. En principio, nuestro interés por el discurso ensayístico se coloca al margen de los abordajes señalados, puesto que he mos centrado la atención en los aspectos formales del discurso ensayístico, desde una doble perspectiva, diacrónica y genológicaํ. D esde un punto de vista teórico, si admitimos que discurso y contexto constituyen una unidad de análisis², podemos plantear la hipótesis de que, en determinadas situaciones de interacción social, se configuran géneros discursivos específicos, cuya particularidad consiste en la forma en que se haya codificado un contenido, operantes bajo condiciones pragmáticas determinadas. D eacuerdo con este principio, nos proponemos tratar el discurso ensayístico con el propósito de indagar la inherencia moral que se sobreimprime en el mismo. Lo dicho debe entenderse en el sentido de queel ensayo es la forma más apta para la expresión de ciertos contenidos críticos $^{3}$, circunstancia que podría marcarse con claridad en períodos específi-

${ }^{1} D$ e esta afirmación general debe exceptuarse la tesis doctoral, publicada recientemente, de M aríaElena Arenas C ruz: $\mathrm{H}$ acia una teoría general de ensayo. Construcción del texto ensayístico. Cuenca, Ediciones de la U niversidad de C astilla-La M ancha, 1997.

2"Los géneros del discurso - escribe Alvarado Jiménez- no son solamente instancias de organización y estructuración intratextuales, sino desempeñan básicamente una función reguladora de los usos sociales del lenguaje en una comunidad histórica y socialmente específica. Por usos del lenguaje entendemos fundamentalmente, los procesos de elaboración e interpretación, la producción y recepción discursivas". Alvarado Jiménez, Ramón: “G éneros y estrategias del discurso". En: Versión, octubre, 1991, p. 86.

${ }^{3}$ La aclaración es válida, por cuanto con el término moral no estamos aludiendo a un posible "deber ser" que valga tanto para el autor y el lector. Una precisión similar ha sido hecha por M iguel Gomes en su estudio sobre los géneros en $\mathrm{H}$ ispanoamérica, aunque con una perspectiva diferente, al declarar que la noción de género, "una vez desprendida de axiologías concretas, simplemente es amoral". G omes, M iguel: Los géner os literarios en H ispanoamérica: Teoría ehistoria. N avarra, EU N SA, 1999, p. 22. Para nosotros, la inherencia moral de la forma ensayística en H ispanoamérica alude, insistimos, a que la forma reúne los requisitos mínimos que la conviertan en la más apta para la expresión de ciertos contenidos, que son de orden interpretativo de una situación contemporánea al emisor. Como tendremos oportunidad de ver en las vinculaciones que hemos establecido con la retórica, las virtudes del ensayista integran un tipo espećifico de argumento. 
cos: como por ejemplo, en momentos de la emergencia del género ensayo durante el Renacimiento (siglo XVI), la Ilustración (XVIII) -por tomar dos instancias de la cultura europea- , y el siglo XIX hispanoamericano. En todos los casos se produce una legitimación del espíritu crítico en consonancia con la admisión del género ensayístico como una opción discursiva indispensable.

Por otro lado, una segunda motivación guía nuestra reflexión genológica sobre el discurso ensayístico, la que procura inquirir en torno de su condición literaria. Como es sabido, la cuestión de los géneros constituye una de las disputas que ha protagonizado la historia de la poética, desdeA ristóteles hasta nuestros días, y que no pareciera tener una solución definitiva ${ }^{4}$. Si aceptamos el consenso existente en torno a la clásica división tripartita de los géneros literarios, el ensayo no podría ser considerado una escritura artística, de manera que una revisión dela clasificación genérica es uno delos problemas que debemosafrontar con la intención de dilucidar la especificidad literaria del discurso ensayístico. En suma, el estudio genológico nos permite realizar un movimiento de lo particular a lo abstracto, es decir, del texto al género, con el propósito de asentar de pleno derecho al discurso ensayístico dentro de la institución literaria.

\section{DISC URSO EN SAYISTICO E INST ITUCION LITERARIA}

Pero la sola revisión genológica no sería suficiente para despejar acabadamente los problemas planteados. Paul H ernadi ha abogado por una indagación más filosófica que histórica, en un intento de "describir algunos tipos básicos de la literatura que puede escribirse y no las numerosas clases de obras que se han escrito". D eahí que sitúe la discusión en el orden dela literatura y no solamente en los límites entre los géneros literarios5. La reflexión teórica de H ernadi nos

${ }^{4}$ EI problema de los géneros, como reconoce C laudio Guillén, no tiene solución definitiva sino que debe ser puesto en relación con el momento histórico, la época, la escuela y aun con cada talante crítico. G uillén, Claudio: Entre lo uno y lo diverso. Introducción a la literatura comparada. Barcelona, C rítica, 1985, p. 141. Por su lado, y más recientemente, G arcía Berrio ha insistido en esta correlación entre género/historia: "N 0 se ha considerado satisfactoriamente aún el grado de tensión o de modificación introducido por la dialéctica de los factores históricos respecto a las constantes estructural-si stemáticas que regulan las modalidades fundamentales de formulación expresiva y de plasmación de las representaciones de mundos". García Berrio, Antonio, H uerta Calvo, Javier: Los géneros literarios: sistema e historia (U na introducción). M adrid, Cátedra, 1995, pp. 46-47.

${ }^{5} \mathrm{H}$ ernadi, Paul: Teoría de los géneros literarios. Barcelona, Antoni Bosch Editor, 1978, p. 144 (destacado original). 
interesa por el hecho de que plantea la cuestión genérica dentro de los límites de la institución literaria 6 .

Por lo tanto, el enfoque genológico del discurso ensayístico no puede eludir la pregunta sobre la institución literaria que lo admite o rechaza. En términos generales, la teoría de los géneros clásica le ha negado entidad artística al discurso apelativo-comunicativo por integrar la esfera de lo práctico y lo útil. C omo lo apelativo-comunicativo es lo propio del ensayo, si pretendemos establecer su especificidad literaria habrá que situar el rasgo en el mismo nivel y con la misma entidad que lo expresivo-sintomático, cuya natural eza literaria estaría fuera de dudas, en el proceso de comunicación artística7. Para plantear el problema de los géneros simultáneamente con la pregunta sobre el ser de la literatura y evitar hundirnos en un abismo, el interrogante sobre el ser de la literatura debe formularse en relación con el discurso que intenta hablar de ella, es decir, el

${ }^{6} \mathrm{G}$ omes al comentar el pasaje inicial de la Poética de Aristóteles ("M e propongo tratar de la Poesía en sí misma y de sus tipos diversos") dice: "En efecto, aunque la formulación ofrece un quehacer dual, sabemos que en las páginas siguientes no existe tal deslinde y, forzosa, obstinadamente, la 'Poesía en sí misma' parece asequible sólo mediante 'los tipos', la pluralidad que en el fondo signa a todo esencia reconocible". Gomes, M iguel: 0 p. cit., p. 16.

${ }^{7} \mathrm{G}$ arcía Berrio explica que existeuna correspondencia entrelas dos modalidades dialécticas, relativa a la percepción y representación subjetivo-objetiva del mundo como dialéctica de identidad-alteridad y los modos de expresión del discurso literario. La tradición especulativa indica que los principios enunciativo y simbólico de la literatura se fundamentan en la experiencia artística de la alteridad. En la diferencia entre la diégesis si ntomático-expresiva de la lírica y mímesis representativo-comunicativa se despliega dialécticamente la indagación subjetiva como experiencia de la identidad descubierta y de la alteridad como conciencia de lo otro diferente. La realidad es descubierta y comunicada del mismo modo dentro de la esfera del conocimiento como del arte, la diferencia estriba en las capacidades puestas en funcionamiento y los resultados (imágenes artísticas y conceptos intelectuales). G arcía Berrio, Antonio, H uerta C alvo, Javier: L os géneros literarios: sistema e historia (U na introducción), p. 53. Para Lukács: "Lo ofrecido por la obra de arte puede ser al mismo tiempo más y menos que conocimiento. M ás que conocimiento, porque el arte es a menudo capaz de descubrir hechos hasta entonces inaccesibles al conocimiento, y puedehacerlo de un modo tal que su trasposición en conocimiento desantropomorfizador siga siendo imposible durante mucho tiempo; hasta puede tratarse de ampliaciones de nuestro conocimiento del mundo y de nosotros mismos que, por diversas razones, no vayan a tener nunca una descripción exacta en el sentido de los sistemas conceptuales del conocimiento. Y es también menos que éste porque lo ofrecido por el arte, visto en la perspectiva y la metodología de la ciencia, no puede tener nunca más que el carácter de una facticidad". Lukács, G eorg: Estética, I. La peculiaridad de lo estético. Trad. M anuel Sacristán. Barcelona, G rijalbo, 1966, p. 180. D esde esta perspectiva se hace más comprensible, según Lukács, que las grandes de obras de la literatura didáctica sean capaces de retener su efectividad artística, después de que las nuevas ideas han reemplazado a la mayoría de sus enseñanzas. 
objetivo final -una ontología de la literatura- se sustituye por el recorrido ${ }^{8}$. Como la propiedad literaria del discurso ensayístico no es un asunto sencillo de resolver, su consideración no es para zanjarlo definitivamente, sino que, de su esclarecimiento, pretendemos obtener algunos puntos de apoyo para la orientación de nuestras reflexiones. ${ }^{9}$. El recorrido, entonces, puede allanarnos el camino tanto para la apertura de una cuarta categoría genérica (H ernadi, al igual que otros tratadistas, ha intentado superar el principio monista de clasificación

8Todorov, Tzvetan: L os géneros del discurso. Trad. Jorge Romero León. 1a ed., Caracas, M onte Avila Editores, 1996, p. 12. Sobre la especificidad literaria existen numerosas teorías, las cuales, en su mayoría, han coincidido en que los fundamentos deben buscarse en el lenguaje, soporte material de la literatura. Las aproximaciones de la lingüística a la literatura dieron origen a una teoría del lenguaje literario, que se ha nutrido de la propuesta teórica de Ferdinand de Saussure, de las contribuciones del formalismo ruso, del Círculo de Praga y del método estructural. Roman Jakobson se formuló la pregunta del siguiente modo: “¿Q ué es lo que hace que un mensaje verbal sea una obra de arte?". Jakobson, Roman: Ensayos delingüística general. Seix Barral, p. 348. Con todo, desde mucho antes, con el artículo de Sklovski, "El arte como procedimiento" (1917), se había instalado sólidamente la convicción de que la literatura es lenguaje. Sin embargo, y con el tiempo, la respuesta se ha mostrado ineficaz 0 insatiffactoria, en virtud de que la literatura es algo más que lenguaje. N i Jean Paul Sartre en su conocido libro, ¿Qué es la literatura?, Gerard Genette en Ficción o dicción (Barcelona, Lumen, 1993) o Terry Eagleton en U na introducción a la teoría literaria, han tenido la pretensión de dar una respuesta definitiva al interrogante.

${ }^{9} \mathrm{El}$ asunto ha vuelto a plantearse en un estudio sobre el ensayo hispanoamericano de Clara R ey de Guido. La autora declara en su Advertencia, la necesidad de "distinguir la presencia del ensayo literario dentro de la producción ensayística de H ispanoamérica". Rey de Guido, Clara: Contribuciones al estudio del ensayo en H ispanoamérica. Caracas, Biblioteca de la Academia N acional de H istoria, 1985, p. 9. La autora, luego de poner, en cierto modo, al día la bibliografía existente sobre el ensayo, organiza su investigación en dos partes: la primera se ocupa del origen, sentidos, definiciones y desarrollo del ensayo como género literario, y la segunda, de la bibliografía, acompañada de un comentario. La autora con la distinción que introduce instala nuevamente el interrogante: ¿ensayo literario?, ¿no es acaso el ensayo un género propio de la institución literaria? Es indudable que las ambivalencias que provoca el discurso ensayístico a la hora de clasificarlo como literario o no obedece tanto a la naturaleza propia de su discurso como a las nociones o teorías literarias que sustentan las diferentes respuestas. Hablar sólo del ensayo "con valor literario", como apunta la autora, restringe considerablemente el radio de visión sobre este tipo de discurso, aunque, por otro lado, impone un grado de especificidad necesario en la organización de un corpus ensayístico. Q ué es lo que permite asignar "valor literario" a determinados ensayos y a otros no: ¿los contenidos semánticos de su referente?, ¿el uso especial del lenguaje? D e ser los objetos referenciales, parece una perspectiva muy lábil, ya que, por su referente, muchos ensayos no deberían pensarse dentro del campo literario, sino en el de otras disciplinas: la filosofía, la historia, la sociología, etc. Sin embargo, también estas disciplinas han expulsado de sus esferas a esta prosa por considerarla carente de rigor o cientificidad. La cuestión conviene plantearla no en la esfera de la literariedad, al modo de los formalistas rusos, es decir, un conjunto de rasgos verbales inherentes, sino que la sanción de lo literario proceda del reconocimiento de una modalidad de producción y recepción comunicativa. 
genérica, recurriendo a la noción de sistema conceptual policéntrico ${ }^{10}$ ), como el planteamiento de una tipología del discurso, como lo prefieren Bajtín y Todorov, desde sus respectivos puntos de vista.

Por lo expuesto, nos ha parecido prudente adoptar una concepción del gé nero partiendo de la doble condición que lo caracteriza, es decir, las permanencias sistémicas y las variantes históricas ${ }^{11}$. El género literario, entonces, es un conjunto de constantes semióticas y retóricas, con cierta regularidad histórica y presente en un determinado número de textos literarios. Ello obliga, en primer término, a no confundir los nombres con las propiedades que los informan y en segundo, a hacer hincapié en la relación entre entidad estructural y fenómeno histórico ${ }^{12}$. En el caso determinado del discurso ensayístico, el enfoque dia-

${ }^{10} \mathrm{D}$ esde otra perspectiva, pero preservando un análogo criterio policéntrico, se encuentra el caso deH uerta C alvo que añadea la tríada genérica clásica "Ios géneros didáctico-en sayísticos" que incluyen a casi todas las manifestaciones de la prosa escrita no ficcional, aunque no siempre la voluntad artística esté claramente definida. EI grupo genérico se rige por un criterio temático y no expresivo o referencial. Huerta Calvo, Javier: "Ensayo de una tipología actual de los géneros literarios". En: G arcía Berrio, Antonio, H uerta C alvo, Javier: Los géneros literarios. sistema e historia (U na introducción), p. 147. En la justificación dada por H uerta Calvo para la apertura de la cuarta categoría genérica, se lee: "Incluimos en este apartado aquellos géneros considerados tradicionalmente fuera del ámbito de las Poéticas, por tratar de materia doctrinal y no ficcional. La lengua sirve en ellos para la comunicación del pensamiento en sus diversas facetas: filosófica, religiosa, política, científica/.../ Por consiguiente, el propósito estético queda subordinado en este grupo a los fines ideológicos, sin que pueda afirmar, no obstante, que aquél esté ausente por completo. La forma básica de este grupo, el ensayo, testimonia que en determinadas épocas ha prevalecido un concepto del mismo muy estetizante, hasta el punto de que los límites entre lo didáctico y lo ficcional han llegado a diluirse". I bidem, p. 218. M erece destacarse esta última frase, en virtud de la asimilación impuesta a los conceptos "estetizante" y "ficcional", la manera clásica como ha sido definida la literatura (igualada a ficción). Por otro lado, H ernadi se opone a la constitución del ensayo como un cuarto prototipo genérico, aunque lo reconoce como una "forma de persuasión literaria muy especializada". En su lugar propone como tipo de comunicación impersonal y artística al adagio y las formas afines, en tanto "modelo conceptual de la persuasión temática" dentro del dominio de la literatura imaginativa. Pero tampoco queda muy claro la razón por la cual se debe preferir el adagio en vez del ensayo, sobre todo por la restrictiva concepción que H ernadi tiene de este último. Cuando el ensayo pasa a ser personal y artístico deja de ser temático, por tanto, se acerca a la visión del poeta lírico. H ernadi, Paul: 0 p. cit.

${ }^{11}$ Todorov define un género de la siguiente manera: "L os géneros son entonces unidades que pueden ser descritas desde dos puntos de vista diferentes: el de la observación empírica y el del análisis abstracto. D entro de una sociedad se institucionaliza el constante recurrir de ciertas propiedades discursivas, y los textos individuales son producidos y percibidos en relación a la norma que constituye esta codificación. Un género, literario o no, no es otra cosa que esta codificación de las propiedades discursivas". Todorov, Tzvetan: L os géneros del discurso, p. 52.

${ }^{12} \mathrm{D}$ ucrot, 0 swald, Todorov, Tzvetan: D iccionario enciclopédico de las ciencias del lenguaje. Trad. de Enrique Pezzoni. Buenos Aires, Siglo XXI, 1974, p. 180. 
crónico es el que permite advertir que las primeras tipologías no fueron exhaustivas ni mucho menos podían prever el despliegue de géneros poéticos posteriores ${ }^{13}$

A la pregunta de cómo aparece o desaparece un género, Claudio Guillén ha contestado diciendo que "el género queda establecido sólo por imitación, reiteración o remodelación: los epígonos de M ontaigne erigen el ensayo"14. Dicho en otros términos, el ensayo tiene un origen en la obra de M ontaigne por haberle asignado no sólo la denominación, sino también, y fundamentalmente, por la creación de un modelo. Aunque el género como tal queda instituido desde el momento en que Francis Bacon adopta el modelo y lo continúa. También, la respuesta dada por Guillén al problema de la constitución de un género impone la necesidad de dar cuenta de los principios constructivos que regulan históricamente una clasificación genérica, tanto desde el punto de vista de la conciencia creadora como desde la recepción por parte de una comunidad lectora.

Bajtín supuso que el género debía ser estudiado en sus orígenes: “El género vive en el presente pero siempre recuerda su pasado, susinicios, es representante de la memoria creativa en el proceso del desarrollo literario /.../ Por eso, para una correcta comprensi ón del género es necesario remontarnos a sus orígenes" ${ }^{\prime \prime 2}$. La perspectiva adquiere el carácter de método, en virtud de que el estudio de un texto es incompleto si antes no se establecen las claves genéricas del mismo y la tradición en la que se inserta ${ }^{16}$. Así pues, toda descripción de un texto es una descripción de un género ${ }^{17}$. Sin desdeñar el factor histórico, la flexión hacia el origen del género ensayístico es también sistemática, como consecuencia de

${ }^{13}$ G arcía Berrio, Antonio, H uerta Calvo, Javier, op. cit., p. 11. Por su parte dice Segre: "La simplificación aristotélica era una selección dentro de los géneros históricamente constatados en la G recia arcaica y clásica, por lo tanto no pretendía abarcar todo el ámbito literario. Esta selección ha sido progresivamente generalizada (como si otros géneros no pudieran existir) y ontologizada (casi como si los géneros fueran categorías del espíritu)". Segre, Cesare: Principiosdeanálisis del texto. Trad. M aría Pardo de Santayana. Barcelona, Crítica, 1985, p. 278. A esta simplificación contribuyeron en gran medida los comentaristas del Renacimiento, como piensa Alfonso Reyes en su reflexión sobre la antigua retórica. Y agrega: “Pretender, en plenos siglos modernos, ajustar los fenómenos literarios a supuestos cánones extraídos del análisis que hizo Aristóteles sobre un solo tipo posible de la tragedia, tipo abandonado ya y que ni siquiera correspondía a las nuevas exigencias del espíritu, es uno de los mayores absurdos que registra la historia crítica". Reyes, Alfonso: O bras completas. M éxico, Fondo de Cultura Económica, 1961, t. XIII, p. 203.

${ }^{14}$ Guillén, Claudio: Lo uno y lo diverso, p.144.

${ }^{15}$ Bajtín, M ijail, M .: Problemas de la poética de D ostoievski. Trad. Tatiana Bubnova. M éxico, Fondo de Cultura Económica, 1986, p. 151 (las cursivas son nuestras).

${ }^{16} \mathrm{G}$ arcía Berrio, Antonio, H uerta Calvo, Javier: 0 p. cit., p. 137.

${ }^{17 T}$ Todorov, Tzvetan: "Los géneros literarios". En: Introducción a la literatura fantástica. Trad. de Silvia D elpy. Buenos Aires, Tiempo Contemporáneo, 1972, p. 14. 
que, en términos generales, no existiría un "antes de los géneros" cronológicamente hablando. Todorov, más que una respuesta para algún género en especial, ha planteado el interrogante sobre el origen en los siguientes términos: "¿qué es lo que determina siempre el nacimiento de un género?" ${ }^{18}$. Para ello es indispensable el tratamiento de los géneros literarios desde una perspectiva teórica, principalmente, ya que es propio de la naturaleza del lenguaje su pertenencia a la abstracción, a lo genérico ${ }^{19}$.

Al no existir lo individual en el lenguaje, la especificidad del texto, dice Todorov, se al canza mediantela descripción del género. El alcance metodológico de una reflexión sobre los géneros se aprecia mejor en el hecho de que su estudio significa reconocer las relaciones que el texto mantiene con los textos ya existentes. "Los géneros - sigue Todorov- son precisamente esos eslabones mediante los cuales la obra se relaciona con el universo de la literatura"20. Esta relación se produce mediante un doble movimiento que va de la obra a la literatura (o el género) y de la literatura (del género) a la obra.

Por su parte, García Berrio supone que la plasmación del género, como estructura comunicativa, se produce en el entrecruzamiento de las unidades de contenido temático y las modalidades de realización expresiva que se seleccionan. La historicidad de esta relación permite dar cuenta de las transformaciones que se producen: por hibridación, contaminación o sustitución ${ }^{21}$. García Berrio sostiene que un ajustado tanto como adecuado planteo de una teoría de los géneros literarios consiste en observar la articulación y actualización histórica de las clases expresivas fundadas en presupuestos de universalidad natural genérica22. Sin embargo, el criterio de la "universalidad natural genérica" lejos está de ser admitido pacíficamente por las más recientes teorías sobre el género.

A nuestro juicio, la articulación natural/histórico, en la teoría de los géneros, no puede menos que matizarse en los términos que $G$ enette lo realiza. En efecto, para G enette ninguna instancia es por esencia más natural o más ideal, en razón de que los grandes "tipos" ideales, que se oponen tan frecuentemente a los géneros medios, no son más que formas más amplias y menos especificadas. La distinción entre géneros (categoría propiamente literaria) y modos (ca-

${ }^{18}$ Todorov, Tzvetan: L os géneros del discurso, p. 50.

${ }^{19}$ Todorov, Tzvetan: “Los géneros literarios”, p. 22.

${ }^{20}$ bidem, p. 15.

${ }^{21} \mathrm{G}$ arcía Berrio, Antonio, H uerta Calvo, Javier: O p. cit., p. 18. “¿D e dónde vienen los géneros? - se pregunta Todorov- . Pues bien, simplemente de otros géneros. Un nuevo género siempre es la transformación de uno o varios géneros antiguos: ya sea por inversión, desplazamiento o combinación". Todorov, T.: Los géneros del discurso, p. 50.

${ }^{22} \mathrm{G}$ arcía Berrio, Antonio, H uerta C alvo, Javier: O p. cit., p. 16. 
tegorías que dependen de la lingüística) es, empíricamente, la diferencia existente entre relato (modo) y novela (género):

No pretendo - escribe Genette- de ninguna manera negar para los géneros literarios toda clase de fundamento "natural" y transhistórico: considero, por el contrario, como otra evidencia (ambigua) la existencia de una postura existencial, de una "estructura antropológica" (D urand), de una "disposición mental" (Jolles), deun "esquema imaginativo" (M auron), o, como diríamos corrientemente, de un "sentimiento" propiamente épico, lírico, dramático - pero también trágico, cómico, elegíaco, fantástico, novelesco, etc.-, cuya naturaleza, el origen, la permanencia y la relación con la historia (entre otras cosas) quedan aún por estudiar. N iego solamente que una última instancia genérica, y sólo ésta, pueda definirse por medio de términos que excluyen lo histórico: cualquiera que sea el nivel de generalidad en que nos situemos, el hecho genérico mezcla inextricablemente el hecho natural y el hecho cultural, entre otros ${ }^{23}$.

Así pues, queel ensayo no pertenezca a ningún género de la tripartición más admitida (lírica, dramática o épica) no aporta más que una diferenciación superficial, discernible por cualquier lector medio, capaz de distinguir la prosa argumentativa de un relato, por ejemplo.

\section{POETICA ESEN CIALISTA Y POETICA CON DICION ALISTA}

Para poder despejar estos asuntos sería conveniente referirnos a los criterios fundamentales que han funcionado en la asignación de la propiedad literaria a los textos. Digamos para empezar que estos criterios, a grandes rasgos, se engloban en lo que también Genette ha denominado, por un lado, poética esencialistay, por otro, poética condicionalista. La primera seinterroga por "las razones objetivas, inmanentes 0 inherentes al texto mismo y que lo acompañan en todas las circunstancias", la segunda lo hace en función de las condiciones en las que un texto pasa a ser una obra o, a la inversa, es decir, cuando deja de serlo. La poética esencial ista es cerrada y en un sentido amplio se corresponde con las poéticas clásicas, la condicionalista, en cambio, es abierta. G enette introduce una distinción más en la poética esencial ista, según sigan un criterio temático 0 un criterio formal. D e manera que la poética esencialista en su versión temática de más prestigio y perdurabilidad ha sido la de Aristóteles, que resuel ve la especificidad literaria mediante una respuesta radical: hay creación por el lenguaje

${ }^{23} \mathrm{G}$ enette, Gerard: "'G éneros', 'tipos', 'modos'. En: Garrido Gallardo, M iguel (comp.): Teoría de los géneros literarios. M adrid, Arcos/Libros, 1988, p. 230. 
si hay mímesis, es decir representación de acciones y acontecimientos imaginarios. Si lo que hace el poeta no es la dicción sino la ficción, razona G enette, se explica entonces la ausencia de todo texto no ficcional en las poéticas clásicas.

El criterio mimético, extremadamente limitativo, dejaba fuera del estatuto poético a la poesía lírica, didáctica o de otra índole. Para sanear el principio restrictivo se ha intentado o asignar valor "imitativo" a la poesía o seguir una vía más concluyente, la que "rompe con el dogma y proclama la igualdad, en lo que atañea la dignidad poética, de una expresión no representativa"24. Así como la poesía lírica no ha podido estar ausente del estatuto poético, sólo por el hecho de no ser "representativa", del mismo modo otros enunciados reclaman su lugar dentro de la poética, en virtud de que la poética esencialista (en su versión temática o formal) por fuerza no abarca la totalidad de la esfera literaria. Su mayor fal encia radica en el hecho de que escapa a su dominio "Ia literatura no ficcional en prosa: historia, elocuencia, ensayo, autobiografía"25. Por constituirse cerradamente, esta poética admite como textos pertenecientes a la literatura tan sólo a aquellos que contengan la marca archigenérica de la ficcionalidad 0 la poeticidad. La misma dificultad que se presenta con la poesía para atribuirle la categoría de ficción, y este impedimento complica su inclusión dentro de una definición de literatura signada por la mímesis, se visualiza con el discurso ensayístico. No por el problema de su propiedad ficcional, pues se descarta de antemano por la fuerte relación que establece con la realidad, sino porque no hay márgenes para exponer problemas diferentes a partir de una poética de un solo rasgo archigenérico.

Es ostensible la incapacidad de la poética esencial ista para considerar literarios a aquel los textos carentes de marca archigenérica, lo que obliga a ponderar los al cances de la poética condicionalista con el objeto de determinar las propiedades literarias del discurso ensayístico. En el centro de esta poética se coloca el estilo, como la capacidad literaria de todo texto, puesto que gracias a esa voluntad de estilo - diríamos con términos de Juan $M$ arichal- un texto alcanza trascendencia estética, aunque no haya sido ésa la función inicial para la cual fue creado $^{26}$. G enette pone como ejemplos la carta 0 el discurso que, más allá

${ }^{24}$ bidem.

${ }^{25} \mathrm{G}$ enette, G érard: Ficción o dicción. Trad. de Carlos M anzano. Barcelona, Lumen, 1993, p. 23.

${ }^{26} \mathrm{D}$ ice Eagleton: "Un escrito puede comenzar a vivir como historia o filosofía y, posteriormente, ser clasificado como literatura; o bien puede empezar como literatura y acabar apreciado por su valor arqueológico. Algunos textos nacen literarios; otros se les impone el carácter literario". Eagleton, Terry: Una introducción a la teoría literaria, p. 19. Eagleton discute los principales criterios de la literariedad: ficción/imaginación, uso característico del lenguaje, el discurso no pragmático, y el valor literario como ideología. 
de su destino original y su motivo práctico, pueden encontrar admiradores. En otras palabras, la actitud estética y la aprobación teórica o pragmática no son, en última instancia, incompatibles ni es necesario que para que una exista deba desaparecer la otra. Por el contrario, la inteligencia puede estar seducida y convencida a un mismo tiempo. Según el principio condicionalista, los límites de la literatura se amplían, por efecto de la "recuperación estética, queactúa en ésa como en otras esferas y abona en la cuenta del arte una gran parte de lo que la acción del tiempo substrae a la de la verdad o la utilidad: por eso resulta más fácil a un texto entrar en la esfera literaria que salir de ella"27.

Para la poética esencialista el estatuto literario se sitúa al margen de la esfera de la utilidad del lenguaje, de tal modo que la literatura sería el resultado del uso del lenguaje sin fines prácticos inmediatos, como si el contenido de un enunciado no contara en la constitución final del objeto estético. Si así fuera, el discurso ensayístico debería leerse prescindiendo del valor-verdad que contiene, en favor de la forma como ha sido expresado ${ }^{28}$. La pertinencia teórica de una poética esencialista parece indiscutible, pero deja sin resolver un cúmulo de enunciados que revisten calidad estética, por lo tanto se constituyen en objetos estéticos, al margen de si ésa ha sido o no la finalidad original. Pero también están aquellos textos que por su voluntad de estilo se conciben con una clara intención estética, al mismo tiempo que como discursos perlocutivos, es decir, con fines pragmáticos. El discurso ensayístico reúne ambas categorías: voluntad de estilo (intención estética) y uso pragmático de la lengua (finalidad persuasiva), de ahí que su consideración sólo sea factible hacerse desde la vertiente de una poética condicionalista.

El hecho de que no exista un acto de habla específicamente literario sólo significa que la literatura, entendida como actos verbales rituales, puede com-

${ }^{27} \mathrm{G}$ enette, Gérard: Ficción y dicción, p. 25. En rigor, son los límites de la estética los que se amplían, o como Luis Beltrán Almería lo llama: "ampliación del capital estético". La tesis de Beltrán Almería consiste en proponer que frente al agotamiento de las fuentes originarias del arte, durante la M odernidad, tiene lugar una "reacción cultural" que procura nuevos materiales para el arte y allanar así su renacimiento. B eltrán Almería sostiene que los géneros retóricos son los que proveen tales materiales para la estetización. Ya volveremos sobre el tema. Beltrán Almería, Luis: "El debate sobre la naturaleza estética de la retórica". En: Albaladejo, Tomás, D el Río, Emilio, C aballero, José Antonio (eds.): Q uintiliano: H istoria y actualidad de la retórica. Logroño: Instituto de Estudios Riojanos; Calhorra: Ayuntamiento, 1998, vol. II, p. 480.

${ }^{28}$ "Un texto de prosa no ficcional - escribe $\mathrm{G}$ enette- puede muy bien provocar una reacción estética que se deba no a su forma, sino a su contenido: por ejemplo, podemos reconocer y apreciar como objetos estéticos, independientemente de la forma con que estén contados, una acción o un acontecimiento real relatado por un historiador 0 un autobiógrafo /.../." Ibidem, p. 32. 
partir ciertos actos con otros discursos, lo que los coloca en el mismo nivel de pertenencia, es decir, el lenguaje. A riesgo de parecer obvia es la principal conclusión extraíble. Pero no alcanza para diluir las diferencias entre estos discursos, aun admitiendo que la "aceptación" efectiva de la literatura debe ser buscada fuera de los niveles pragmáticos: "en sistemas de normas y valores (estéticos) social, histórica y culturalmente determinados"29.

\section{GENERO Y VOLUNTAD EXPRESIVA}

Por lo expuesto, la cuestión de los géneros conviene encuadrarla en la equidistancia entre el carácter convencional que poseen y la voluntad creadora que subyace en cada uno de ellos. D esde el punto de vista teórico, W ellek y Warren organizaron la reflexión sobre los géneros literarios al rededor de cuatro interrogantes: 1. Si va implícito en una teoría de los géneros literarios el supuesto de que toda obra pertenece a un género; 2 . En qué grado está implícita la intención en la idea de género; 3 . Si la intención le corresponde a un precursor o la intención pertenece a otros; 4 . Si quedan fijos los géneros ${ }^{30}$. El primer interrogante los autores lo responden afirmativamente aduciendo que todo es susceptible de clasificarse; en relación con el último aseguran que los géneros no quedan fijos. En cuanto a las preguntas restantes, apuntan a aspectos de interés para nuestro propósito.

La idea de "intención" articula la problemática de los géneros con modos diferentes de representación del mundo: de un lado, el género definido como un conjunto de normativas, que constituyen un modelo cognitivo, al que el escritor se ajusta, de otro, el género como una actitud ante la vida y el mundo circundante. Ambas perspectivas están ajustadas a los siguientes binomios: forma-actitud, actitud-forma, de modo que la expresión literaria se estructuraría sobre la base de tres nivel es ${ }^{31}$, las actitudes básicas (narrativa, dramática, lírica), los modos y procedimientos de composición conectados con tales actitudes y los asuntos apropiados en función de los otros dos niveles. La multiplicidad de combinaciones de estos niveles está fuera de duda, con arreglo a lo cual se

${ }^{29}$ D ijk, Teun A. van: “La pragmática de la comunicación literaria”, p. 194.

${ }^{30}$ Wellek, René, Warren, Austin: Teoría literaria. Ver. esp. José M. G imeno. 4a ed., M adrid, Gredos, 1966, p. 272.

${ }^{31}$ W illiams, Raymond: M arxismo y literatura. Trad. Pablo D i M asso. Barcelona, Península, 1980, p. 210. 
obtiene un concepto dinámico de las poéticas ${ }^{32}$. Pues bien, se debe averiguar si es posible la constitución de una actitud distinta de las tres mencionadas.

El hecho de queintroduzcamosla intencionalidad relativa aun género plantea la necesidad de averiguar en qué esfera se desenvuelve esta voluntad creadora. En principio, no puede atribuirse exclusivamente a un precursor, en nuestro caso nada más quea $M$ ontaigne, sino a una competencia colectiva, manifestada en la tradición cultural y el sistema literario respectivo ${ }^{33}$, de ineludible referencia para el artista, al momento dela plasmación del tema y la selección dela modalidad expresiva. La acción implícita en un género también significa, y muy especialmente, un modo de aprehender la realidad, que abre "las posibilidades fundamentales del ser, las cuales no tienen otra realidad que la de poner al descubierto la manera de manifestarse lo existente, los objetos y los estados" 34 . La expresión y representación de la conciencia humana, que como necesidad comunicativa no tiene cabida en la poética tradicional (épica, lírica, dramática), fue una observación hecha por G. Lukács ${ }^{35}$.

La duda, la perplejidad y el asombro frente a lo que se quiere hacer comprensible, cuyo intento es en sí mismo una pregunta que encierra elusivamente una respuesta, se depositan en la actitud del hombre que ensaya la percepción esencial del mundo y de la vida. Si bien las intenciones han servido de soporte a la división tripartita de los géneros literarios, también es lícito presentar una visión genérica más flexible y clasificaciones ajustadas a la variabilidad de las formas y las necesidades comunicativas. H emos propuesto la necesidad de encontrar la manera de referirnos a la representación de la conciencia humana, en cuanto a dar expresión a las experiencias emotivas de la intelectualidad y conceptualidad que no son posibles en los estrictos marcos de una poética clásica.

32“EI género - expresa Bajtín- es siempre el mismo y otro simultáneamente, siempre es viejo y nuevo, renace y se renueva en cada nueva etapa del desarrollo literario y en cada obra individual de un género determinado. En ello consiste la vida del género". Bajtín, M ijail M .: "El problema de los géneros discursivos", p. 150. "Los antiguos sistemas - escribe Todorovsabían solamente describir el resultado muerto; es necesario aprender a presentar los géneros como principios de producción dinámicos/.../". Todorov, Tzvetan: L os géneros del discurso, p. 55.

${ }^{33} \mathrm{Es}$, como lo señala W illiams, el contenido social ehistórico de una teoría de los géneros. L a actitud básica o posición "es una relación social dada una forma particular de organización sociocultural, y que los modos de composición formal, dentro de la escala que se desarrolla desde lo tradicional a lo innovador, constituyen necesariamente formas de un lenguaje social". W illiams, Raymond: M arxismo y literatura, p. 211.

${ }^{34}$ Staiger, Emil: 0 p. cit., p. 214.

${ }^{35}$ Lukács, G eorg: "Sobre la esencia y forma del ensayo (C arta a Leo Popper)". En: Lukács, Georg: Teoría de la novela. Trad. M anuel Sacristán. Grijalbo, M éxico, 1985, p. 23. 
La opción por una modalidad discursiva en prosa no mimética, sin la alternancia de la primera y la segunda persona y con una estructura argumentativa (requisitos formales mínimos para designar a un ensayo), incide en la plasmación del tema y las estrategias comunicativas entre el autor y los receptores ${ }^{36}$. La elección de una u otra modalidad, al no ser indiferente a la configuración expresiva, nos obliga a plantearnos la cuestión de las intenciones implícitas en un género, sin que con ello hagamos de la psicología de la creación un tema de incumbencia de esta reflexión. Bien dice N . Frye que, aunque la psicología de la creación no constituye un tema del análisis, resulta extremadamente raro que un escritor realice el acto de escribir sin "una noción siquiera de lo que pretende producir"37, a lo que podría agregarse que, en efecto, existe un plan global del discurso como resultado de un proyecto semántico-pragmático del hablante, quien busca que su discurso logre la eficacia en el objetivo fijado, es decir, que el receptor reconozca la intención que ha sido inscripta en el discurso.

Según la teoría de la competencia genérica formulada por M . L. Ryan, para la definición de las categorías genéricas son necesarias por lo menos tres series de requisitos: 1 . Reglas pragmáticas (a la que pertenece la motivación); 2 . Reglas semánticas (especifican el contenido mínimo de los textos de un mismo género); 3. Requisitos a nivel de superficie (referido a las propiedades verbales de los géneros). Entre las reglas pragmáticas existe una motivación general del emisor al momento de producir el texto, aunque difícil de discernir se puede extraer de la fuerza ilocutoria del texto. M . L. Ryan sostiene que la motivación opera a niveles de la representación de la real idad, lo que ayuda a distinguir, por ejemplo, la producción de un anuncio de la producción de un discurso científico, de donde resulta que "la motivación es un factor constituyente del género", por lo tanto una propiedad suficiente para el establecimiento de tres tipos principales de orientación: acción, información y fruición o entretenimiento ${ }^{38}$.

Por su lado, en la construcción del discurso, Bajtín observa un comportamiento especial que consiste en anteponer la totalidad del enunciado a través de dos maneras: en forma de esquema genérico o en forma de una intención discursiva individual. La idea de totalidad creada por el hablante condiciona la elección de las palabras que habrán de integrar el enunciado e irradia la expre-

${ }^{36} \mathrm{G}$ enette, Gérard: "'G éneros', 'tipos', 'modos', p. 15.

${ }^{37}$ Frye, N orthrop: Anatomía de la crítica, p. 323.

${ }^{38}$ Ryan, M arie-Laure: "H acia una teoría de la competencia genérica". En: Garrido G allardo, M iguel (comp.): Teoría delos géneros literarios, p. 268. Es poca la distancia que existe entre los tres tipos principales de orientación genérica (acción, información y fruición) y los tres componentes básicos de la persuasión previstos por la retórica: 'movere', 'docere' y 'delectare'. D esde el punto de vista de las motivaciones es factible delimitar la función social de un género. 
sividad (la emotividad, la evaluación) ${ }^{39}$. En razón de que las palabras carecen de expresividad, esto es, son de natural eza neutra, sólo al ponerlas en contacto con la realidad del enunciado es como se genera la expresividad. D entro del universo neutro de las palabras, la estructuración de un enunciado se real iza mediante la elección de la palabra que pertenece a otro enunciado afín genéricamente (por el tema, la estructura, el estilo). La elección, entonces, se corresponde con una especificación genérica, o sea, el "género discursivo -escribe Bajtín- no es una forma lingüística, sino una forma típica de enunciado; como tal, el género incluye una expresividad determinada propia del género dado. D entro del género la palabra adquiere cierta expresividad típica" ${ }^{40}$. La expresividad típica del enunciado puede encerrar la intencionalidad del emisor.

\section{SUBJETIVIZACION DE LA MAT ERIA VERBAL}

El problema de la intencionalidad que hemos presentado nos lleva a considerar otra instancia consecuente de aquél, esto es, la subjetivización del discurso. Un punto de partida de la subjetivización de la materia verbal puede remontarse al antiguo género del diálogo socrático. En tal sentido, Bajtín pone las palabras de Sócrates en la Apología, mientras espera la muerte, como ejemplo de lo que llama "diálogo en el umbral"41. La escritura ensayística no se desentiende de la manifestación de situaciones excepcionales como la precedente. Se trata de momentos en los que el autor se asoma a ciertos abismos ininteligibles de la vida, del hombre y su destino. Si traemos el ejemplo, lo es porque Lukács, al reflexionar sobre el ensayo, remarca la excepcionalidad de la existencia de Sócrates, cuya vida "es la típica para la forma del ensayo", puesto que "vivió siempre en las cuestiones últimas" y "cualquier otra realidad viva era tan poco viva para él como sus preguntas para los hombres corrientes" 42 .

Asimismo, la sentencia socrática de "conócete a ti mismo" tendrá un largo recorrido, en el cual la obra de San Agustín será un importante hito y la de

39"L os géneros discursivos - escribe Bajtín- organizan nuestro discurso casi de la misma manera como lo organizan las formas gramaticales (sintácticas). A prendemos a plasmar nuestro discurso en formas genéricas, y al oír el discurso ajeno, adivinamos su género desde las primeras palabras, calculamos su aproximado volumen (o la extensión aproximada de la totalidad discursiva), su determinada composición, prevemos su final, o sea que desde el principio percibimos la totalidad discursiva que posteriormente se especifica en el proceso del discurso". Bajtín, M ijail, M .: “El problema de los géneros discursivos”, p. 268.

40Ibidem, p. 277.

${ }^{41}$ bidem, p. 157.

42L ukács, G eorg: "Sobre la esencia y forma del ensayo (Carta a Leo Popper)", pp. 32-33. 
M ontaigne su expresión más moderna. Fuera de toda duda está que, en ninguno de ellos, la significación es la misma, toda vez que la mirada introspectiva guarda diferencias cardinales en cada uno, a pesar de ello, los une un marcado interés por la propia eindividual humanidad. El hombre dela antigüedad prácticamente no habla de su intimidad y cuando lo hace no traspasa los límites de Io anecdótico. Sócrates será, atendiendo estas razones, la extraordinaria excepción. Con posterioridad San Agustín, asentado sobre dos épocas (sin dejar de ser totalmente un hombre antiguo, se proyecta sobre toda la Edad M edia), brinda en sus Confesiones la primera autobiografía de 0 ccidente. Auerbach, comentando el método de M ontaigne de "tomar la vida propia 'cual quiera' en su integridad a fin de estudiar la humaine condition", dice que el autor se presenta a sí mismo como el primero que lo adopta. Aunque Auerbach tiene sus dudas de que sea así, si se piensa en las Confesiones de San Agustín ${ }^{43}$. He aquí otro sentido de subjetivización que cruza la prosa ensayística: el impulso confesional. La propensión a poner al desnudo la intimidad, la "autoinvestigación consecuente", no tan sólo como una inclinación curiosa, sino más bien como un imperativo, que se reconoce en la escritura ensayística, manifiesta la presencia de una voz profundamente internalizada. Este abandono de la "palabra representada" es la consecuencia de la natural eza subjetiva del género, desde cuyo plano se rompe, en cierto modo, con las diversas mediaciones que otros géneros estructuran en la relación autor-destinatario.

En tal sentido, no es improbable que lo que Bajtín llama "diálogos en el umbral" afecte a una amplia franja de la obra de San Agustín. En efecto, la palabra, purificada y despojada de su "automatismo" es el resultado, en el autor de las Confesiones y Retractaciones, de una experiencia mística, que al mismo tiempo deviene de sus radicales preguntas sobre la vida, el destino, el alma, D ios. Estos interrogantes no están mediatizados por subterfugio literario alguno, sino solamente por aquel que emerja del tono confesional. Pareciera ser, entonces, que el cuestionamiento de las cosas esenciales alambica los usos automatizados de la palabra, cuyo resultado es un grado más puro de comunicación. Tal modo de proceder se revela como una constante desde la antigüedad hasta el ensayo moderno, sin que por ello, desde luego, no sea posible identificar una codificación.

${ }^{43}$ Auerbach, Erich: M imesis: la representación dela realidad en la literatura occidental. Trad. del. Villanueva y E. Imaz. Fondo de Cultura Económica, M éxico, 1950, p. 279. 


\section{H UM ANISM O, MODERNIDAD Y EMERGEN CIA DEL EN SAYO}

En consonancia con lo dicho precedentemente, una visón histórica del género ensayístico no puede prescindir de dos condicionamientos específicos. En primer lugar, la consideración de la relevancia conferida al individuo en el sistema social y, consecuentemente, los grados de representación de la subjetividad o su represión ${ }^{44}$. M edardo Vitier, luego de señalar la importancia del humanismo en la historia del ensayo en cuanto a "la jerarquía a que se elevó la conciencia individual", agrega que el proceso searticula, en el momento de su grado máximo duranteel S. XVIII, con los cambios en "la metodología de las ciencias, que abatió todo principio de autoridad intelectual"45. D e manera que el segundo vector de la genealogía del género es la declinación de toda autoridad intelectual y, por tanto, la revolución producida en la metodología de las ciencias. En suma, podríamos decir que estas alteraciones provocan una subjetivización en el saber.

A hora bien, hemos dicho que la identidad de un género proviene, por analogía, del acto de lenguaje que representa. A su vez, cada sociedad elige y codifica los actos de habla que corresponden exactamente a su ideología, por lo que - sugiere Todorov- "tanto la existencia de ciertos géneros en una sociedad, o su ausencia en otra, son reveladoras de esta ideología y nos permiten precisarla más o menos con una gran certeza" 46 . Luego, al haber una relación inmediata entre género e ideología dominante, que ha propiciado la epopeya en una época y la novela en otra, para tomar dos ejemplos, la emergencia del discurso ensayístico durante períodos de alta estimación del individuo y su capacidad para dirimir los conflictos mediante el discurso, se hace más inteligible.

El discurso ensayístico, por tratarse de una producción discursiva netamente de la modernidad, nos obliga a formular algunos interrogantes en torno a la estrecha vinculación existente entre el marco histórico-cultural y la emergencia de la prosa ensayística ${ }^{47}$. La emergencia del ensayo es un fenómeno literario en

44“ L L historia del yo en la retórica de los géneros se vincula con las disposiciones que rigen en la sociedad sobre el lugar del individuo, la legitimidad de la primera persona, que se semantiza, en diferentes situaciones históricas, en el pronombre yo, la extensión y, eventualmente, expresión de una subjetividad admisible". Altamirano, Carlos, Sarlo, B eatriz: Literatura/Sociedad, p. 125. A este punto nos referiremos en el apartado sobre el Renacimiento y el ensayo.

45V itier, M edardo, D el ensayo americano, Fondo de C ultura Económica, M éxico, 1945, p. 19.

${ }^{46}$ Todorov, Tzvetan: L os géneros del discurso, p. 54.

${ }^{47} \mathrm{Sin}$ duda es difícil adoptar una concepción acabada del Renacimiento, ya que aún se continúan debatiendo ciertas facetas del movimiento. Juan $M$ arichal en su indagación de las huellas del ensayismo hispánico en el Renacimiento recoge una de las polémicas, precisamente 
el que están en juego de manera decisiva diversos factores cosmovisionarios de la época moderna. Entre los más destacables, se encuentra la conciencia de la individualidad, tenida como rasgo dominante del Renacimiento, pero también como uno de los más propios del discurso ensayístico ${ }^{48}$. Al margen de ciertos criterios cronológicos, existe una aceptación general respecto del rol que el individual ismo juega en la emergencia del discurso ensayístico ${ }^{49}$.

la que se refiere al "descubrimiento del individuo" como rasgo característico del hombre renacentista. "La novedad renacentista - escribe M arichal-, en cuanto a la debatida cuestión de la conciencia de la individualidad, se manifiesta no tanto en el contenido mismo de la revelación autobiográfica como en su significación 'funcional'". M arichal, Juan: Teoría e historia del ensayismo hispánico. Alianza, M adrid, 1984, p. 71. Algunas monumentales interpretaciones del Renacimiento, como las de Burckhardt y M ichelet, concibieron al movimiento en favor de sus conveniencias ideológicas, para ello forjaron un concepto a la medida de sus necesidades. H auser así lo interpreta: "El liberalismo contrapone el Renacimiento sencillo y amante de la naturaleza a la Edad M edia para combatir así a la filosofía romántica de la historia. Cuando Burckhardt dice que el 'descubrimiento del mundo y del hombre' es obra del Renacimiento, su tesis es a un tiempo un ataque a la reacción romántica y una defensa contra la propaganda destinada a difundir la visión romántica de la cultura medieval. La relación de este concepto del Renacimiento con la ideología del liberalismo es todavía más clara en M ichelet que en Burckhardt /.../". H auser, Arnold: H istoria social dela literatura y del arte. Trad. A. Tovar y F.P. Varas-Reyes. Labor/Punto O mega, Barcelona, 1983, t. 1, p. 335. Ahora bien, considerar los movimientos culturales como fenómenos compartimentados y negados unos con otros, tan sólo contribuye a obtener versiones parcializadas del hombre y su contexto. Los cambios operados entre una época y otra no son en absoluto disruptivos. Ante todo, porque los entramados históricos, sociales y culturales repelen las líneas divisorias infranqueables. En tal sentido, M ichelet y Burckhardt elaboran conceptos cerrados sobre el Renacimiento, al oponerlo a la Edad M edia como "la luz a las tinieblas". "Los modernos estudios - escribe Sáenz H ayes- demuestran que la Edad M edia no fue tan oscura ni tan bárbara según dieron en tenerla Erasmo y los humanistas italianos /.../ (existe una barrera) en la imaginación de los que conciben la Edad M edia y el Renacimiento como dos culturas antagónicas, sin nexo lógico y sin evolución posible de la una a la otra". Sáenz H ayes, Ricardo: M iguel de M ontaigne (1533-1592). Espasa-Calpe, Buenos Aires, 1939, p. 54.

${ }^{48} \mathrm{~A}$. Gurevich plantea el problema del individualismo en función de la "formación de Europa" mediante la siguiente pregunta: "¿N o será que lo que convirtió este continente en la moderna Europa, un mundo aislado formado por diversas civilizaciones, en una única superficie donde se desplegó el proceso histórico mundial, estaría condicionado en última instancia por la estructura específica de la personalidad que se estaba formando precisamente aquí?" G urevich, Aarón: L os orígenes del individualismo europeo. Trad. de M aría G arcía Barris. BarceIona, Crítica, 1997, p. 10.

${ }^{49} \mathrm{Angel}$ del Río sostiene un criterio distinto sobre el individualismo en el ensayo, al situarlo en otra etapa, con lo que varía la cronología pero no el valor constitutivo del individualismo: "Por eso puede afirmarse que la adopción del ensayo como forma es quizás uno de los rasgos más significativos de la sensibilidad contemporánea en España, siendo consecuencia directa del individualismo intelectual y neorromántico característico de las últimas generaciones literarias". Río, Angel del, Bernadete, M . E.: El concepto contemporáneo de España. 
La relación aludida se hace extensiva al tránsito de los géneros primarios a los géneros secundarios, a través de los géneros retóricos. D e conformidad con ello, Beltrán Almería ha planteado que no es una casualidad que "en cada época haya un género que ostenta una hegemonía y una autoridad manifiesta sobre los demás" como tampoco "que ese género sea retórico". Beltrán Almería reserva a estos géneros la función de "umbrales de la cultura" y en ello se hallaría la causa de su hegemonía. La tesis resulta atractiva, además, porque con ella el crítico explica la manera como la esfera de la cultura se al imenta de fenómenos cotidianos, cuya sumatoria producen determinadoscambios ${ }^{50}$. Beltrán Almería ilustra su afirmación con un estudio de Lázaro Carreter referido al cambio lingüístico. Lázaro Carreter niega un papel transformador del lenguaje a los poetas, trasladando tal función a otros agentes innovadores como son los predicadores, políticos, es decir, profesionales de la retórica. La difusión del gongorismo, ejemplifica Lázaro, habría tenido lugar gracias a que se puso de moda entre los predicadores ${ }^{51}$. Sin dudas que estas observaciones reseñadas deben conectarse con la revolución en los soportes técnicos que facilitan la emergencia de otros géneros discursivos a partir del Renacimiento. El periodismo resultará el género retórico más relevante de los nuevos que surgen y se convertirá en portador de cambios discursivos.

En la idea del yo renacentista está semantizada la confianza y seguridad que el individuo ha elaborado sobre sus facultades racionales, capaces de dar inteligibilidad al mundo circundante mediante la razón. La crítica, en general, admite que el proceso de la "conciencia del sí mismo" plantea también una cuestión de objetos y de métodos, en virtud de que el trabajo de investigación no se hace sobre individuos concretos, sino sobre la base de textos, es decir, estructuras verbales que han expresado el individualismo. En tal sentido, A. Gurevich piensa que sería más pertinente hablar, ya no de individualidad, con el riesgo

Antología de ensayos (1895-1931). Losada, Buenos Aires, 1946, p. 14. Por su parte, escribe Sáenz H ayes: "La antigüedad grecorromana tiene fieles continuadores en los padres de la I glesia que, con San Agustín, afirman que la conciencia es el centro de toda verdad y el conocerse a sí mismo la primera y más noble función del espíritu. ¿Cómo se llega al cabal conocimiento de cuanto bulle en nuestro ser? Mucho antes que Montaigne, San Agustín emprende la tarea de pintarse a sí mismo moralmente en las Confesiones, intelectualmente en las Retractaciones /.../ En cambio el "yo" de M ontaigne lo es en grado espectacular y soberbio /.../ Es el suyo el "yo" altanero y cínico del hombre del Renacimiento, en plena liberación y realización. La liberación renacentista consiste en el descubrimiento del hombre por el hombre". Sáenz H ayes, Ricardo: 0 p. cit., p. 55.

${ }^{50}$ Beltrán Almería, Luis: "El debate sobre la naturaleza estética de la retórica", p. 476.

${ }^{51}$ Lázaro C arreter, Fernando: "Lenguajey generaciones". En: Estudios de lingüística. C rítica, Barcelona, 1980, pp. 249-251. 
de operar libremente con términos de la psicología, sino de "mecanismos" sociales, culturales 0 semióticos de la individualización ${ }^{52}$. Es así como la emergencia del ensayo podría pensarse en términos de estos mecanismos semióticos de individualización, según las razones que expondremos.

C arlos Bousoño ha sostenido que el individualismo, en la historia cultural del hombre, ha funcionado como motor de los cambios cosmovisionarios. Según su tesis, "todos los rasgos, no sólo los artísticos y literarios, de una época tienen, en lo fundamental, una explicación unitaria: la cosmovisión que es inherente a tal período"53. A su vez, una cosmovisión se define como un sistema organizado, de tal modo que cada elemento se vincula con los demás. Todas las cosmovisiones poseen una "raíz genética" a partir de la cual el sistema se engendra, también llamado "foco irradiante". El foco deirradiación de la totalidad de los sistemas es siempreel mismo, "cierto grado de individualismo", es decir "la conciencia que yo tengo de mí mismo en cuanto hombre", todo lo cual induce a pensar a Bousoño que "la historia del hombre es la historia del individualis$\mathrm{mo}^{\prime \prime 5}$. Al no ser posible ponderar directamente el individual ismo, ha de hacerse por los efectos culturales provocados $5^{55}$. Con arreglo a ello, ¿cuáles son las manifestaciones de este fenómeno y qué es lo que permite identificarlas? La racionalidad es lo que acompaña al proceso de "conciencia de mí" que implica el individualismo, en el concepto deBousoñ $0^{56}$ y susmanifestaciones se desglosan en tres componentes: a) la autonomía del individuo frente a D ios (secularización), frente a la naturaleza (desarrollo técnico), frente a la jerarquía de clases

${ }^{52}$ Por lo visto, el problema de la individualidad constituye una preocupación más compleja y abarcadora. Además de ser objeto de la psicología, la filosofía, la sociología lo es también de la historia, por lo menos en dos aspectos, como lo entiende A. Gurevich: 1. Centrado en la investigación de la formación del yo humano, de la personalidad, dentro de un núcleo colectivo y al mismo tiempo la toma de conciencia de la distancia en relación con él, que se evidencia en la dirección tomada hacia la interioridad; 2. La singularidad inherente a la autodefinición de la personalidad que caracteriza a una determinada sociedad. G urevich, Aarón: 0 p. cit., p. 18.

${ }^{53}$ Bousoño, Carlos: Epocas literarias y evolución; Edad M edia, Romanticismo, Epoca Contemporánea. Gredos, M adrid, 1981, t. I, p. 10.

${ }^{54}$ bidem, p. 15. Bousoño se ocupa de las etapas del individualismo que van del último tercio del siglo XI hasta nuestros días. Las etapas son: 1 . U Itimo tercio del siglo XI; 2 . Renacimiento; 3. Siglo XVII; 4. Siglo XVIII; 5. La época contemporánea.

${ }^{55}$ Esta cuestión podría resumirse en el hecho de que las investigaciones deben efectuarse en el nivel dela elite intelectual, que son las que poseían posibilidades de expresarse. Como lo observa Gurevich, de ahí el valor que adquieren los textos, en tanto documentos testimoniales. Gurevich, Aarón: Op. cit., p. 19.

${ }^{56}$ Bousoño, Carlos: Op. cit., p. 16. 
(ruptura de vínculos autoritarios); b) la estimación y el protagonismo asignado al individuo y lo individual; c) el grado de valor conferido a la interioridad ${ }^{57}$.

La racionalidad es un impulso que impone la burguesía a través de la tendencia a la centralización, la eficacia y la especialización ${ }^{58}$. Existiría, según Bousoño, una concomitancia entre el desarrollo del individualismo y factores como los cambios en el desarrollo del capitalismo, las mutaciones en el desarroIlo tecnológico, las transformaciones en el tipo de Estado y la emergencia de una nueva cultura fundada en estos aspectos ${ }^{59}$. Con la salvedad de que es factible distinguir dos momentos en el desarrollo del capitalismo, diferenciados por la internacionalización del capital y la introducción de la máquina de vapor, hacia principios del siglo XIX. D e acuerdo con esta distinción, se podría hablar de un capitalismo temprano y otro moderno ${ }^{60}$, caracterizados, desde el punto de vista cultural, por un humanismo burgués en el primer caso y una racionalidad productiva que diluye los límites de la ética humanística temprana, en el segundo61.

Es de especial interés para nuestros fines el primer humanismo caracterizado por Bousoño, en tanto estructura cosmovisionaria, dentro de la cual emerge el discurso ensayístico con clara conciencia genérica. También, Juan M arichal, en el caso específico del ensayismo hispánico, fija el punto de partida histórico del género alrededor del siglo XV, centuria en la que se conquista el principio de democracia, el ideal de la libertad de pensamiento y de conciencia. A su vez, aun con la excesiva gravitación que Estuardo N úñez confiere al libre examen ${ }^{62}$, como un factor constitutivo en el origen del ensayo, su observación confirma el

${ }^{57}$ |bidem, p. 18.

58“C apitalismo - escribe Bousoño- es, pues, por definición, imperio de la razón, y durante esta época, imperio de la razón racionalista, ya que las notas que acabo de atribuir al primero convienen con exactitud a la última. Y como el individualismo está hecho de racionalidad, no hay duda del efecto individualista que ha detener el auge de tal sistema económico". Ibidem, p. 88.

59! bidem, p. 89

60lbidem, p. 697.

${ }^{61}$ bidem, p. 699.

${ }^{62}$ Estuardo N úñez dice: "Cabe observar que el ensayo se ha generado, en pleno auge renacentista, en países en que prospera la nueva ráfaga del 'libre examen', pues es consustancial con su origen, desenvolvimiento y estructura, esa afinidad con el culto de la libertad. En cierta manera, es el ensayo un género que se emparienta con la R eforma -en lo que dicho movimiento tuvo de repercusión para la cultura y no en su simple aspecto religioso- y se desarrolla ampliamente en los países donde hubo reformadores". N úñez, Estuardo: "Proceso y teoría del ensayo". En: Revista H ispánica M oderna, a. XXXI, № 1-4, oct. 1965, p. 358. Al respecto conviene recordar las afirmaciones de $\mathrm{H}$ auser: "/.../ni la idea del 'libre examen' es una conquista del Renacimiento ni la idea de la personalidad fue totalmente desconocida para la Edad M edia". Hauser, Arnold: H istoria social de la literatura y el arte, p. 337. 
acierto de indagar los vínculos existentes entre este discurso emergente y su contexto. No obstante, resulta incompleta la visualización del "libre examen" de la reforma protestante como un núcleo principal de donde derivar el discurso ensayístico.

La nueva conciencia de la individualidad determina también una nueva concepción del arte durante el Renacimiento, mediante el descubrimiento de la idea del genio. Esto significa que la obra de arte corresponde a una personalidad autónoma, al margen de leyes y preceptivas. La coherencia de la obra de arte se enriquece, ya no dependerá de estrictas reglas compositivas, sino de la personalidad que la concibe, siempre superior e incapaz de expresarse por entero en la realización objetiva. La originalidad y espontaneidad, desconocidas en la Edad M edia, adquieren una relevancia a través de la fuerza creadora de la personalidad artística. El paso de una representación objetiva a una configuración subjetiva es el desplazamiento crucial que se produce en la teoría del arte del Renacimiento ${ }^{63}$. Ello determina la constitución de un nuevo modelo artístico, que se puede observar en la singularidad que alcanzaron los dibujos en el arte pictórico renacentista, como lo ha razonado $\mathrm{H}$ auser ${ }^{64}$.

\section{LA INHEREN CIA MORAL DE LA FORMA}

En relación con aquella subjetivización del saber que mencionamos con anterioridad, el Renacimiento promuevela valoración de otro factor cosmovisionario: la noción de evidencia. D entro del régimen de la evidencia es donde deben interpretarse las nuevas concepciones sobre los hechos, las ideas y los sentimientos, en cuanto soberanos en sí mismos. La evidencia toma diferentes direcciones a partir del siglo XVI: una evidencia personal (en el protestantismo), una evidencia racional (en el cartesianismo) y una evidencia sensible (en el empirismo $)^{65}$. Para una mejor comprensión de la idea del nuevo valor surgido es conveniente remitirla a la filosofía humanista que constituyó el fundamento

63lbidem, pp. 407.408. "La expresión de la personalidad - continúa H auser- se busca y aprecia en el arte mucho antes de que se tenga conciencia de que el arte está orientado no ya hacia un qué objetivo, sino a un subjetivo cómo. Se habla todavía de su contenido de verdad objetivo, cuando ya hace tiempo que el arte ha pasado a ser autoconfesión y adquiere valor general precisamente en cuanto expresión subjetiva. La fuerza de la personalidad, la energía espiritual y la espontaneidad del individuo es la gran experiencia del R enacimiento". I bidem, pp. 408-409.

${ }^{64}$ bidem, p. 411.

${ }^{65}$ Barthes, Roland: Investigaciones retóricas I: La antigua retórica, Trad. Beatriz D orriots. Tiempo Contemporáneo, Buenos Aires, 1974, p. 36. 
más firme del Renacimiento, cuya correspondencia con el capitalismo temprano ha sido señalada por Bousoño. En tal sentido, la teoría epistemológica del 'verum factum' constituye uno de los principios, no sólo de la posterior razón tecnológica, sino de la articulación del conocimiento y la acción, del hacer. Leonardo Da Vinci fue uno de los que mejor planteó el tema al definir a la ciencia y al arte como una "segunda creación", por el discurso o la fantasía. Con ello pone de relieve la actividad creadora del artista que culmina en una experiencia productora y no meramente contemplativa. D esde luego que es propio a estos razonamientos tanto el cumplimiento del ideal formativo del humanismo renacentista como una nueva concepción del arte.

La inherencia moral de ciertas formas verbales, en el Renacimiento, está en relación con el alto valor en el que se situaban los 'studia humanitis', los encargados de moldear y pulir la barbarie del hombre, la magna tarea de llevar al hombre al reino de las virtudes. El hombre es una materia moldeable, de ahí que el saber no sea un conocimiento teórico solamente, sino que tiene una perspectiva configuradora del hombre. El humanismo entiende la tarea del saber como una actividad ética de formación del hombre, en cambio la "modernidad postcartesiana la verá como una tarea epistemológica de clarificación de los contenidos de la razón". Q ueda así instaurada la instancia desde la cual se abrirán dos vías dela modernidad: una vía ética y otra metódica. La primera no olvidará su preocupación por la formación humana del sujeto, la segunda se especializa en el carácter técnico de la producción del saber ${ }^{66}$. Es de sumo interés, en nuestra argumentación, el peso de la ética que informa a ciertas formas artísticas. Resultan construcciones verbal es con intenciones formativas del hombre, con un cierto ideal de mejoramiento de la condición humana. El discurso ensayístico, en cuanto a su naturaleza perlocutiva (discurso con intención de producir un efecto), conserva la preocupación por el hombre, resistiendo la otra vía de la modernidad, la metódica, instaurada a partir de D escartes. Frente al metodismo postcartesiano se erige la divagación ensayística, no como una forma inacabada sino abierta, no conclusiva y no autoritaria. La disputa de las direcciones de la modernidad, la ética y la metódica es el tema que Adorno adopta en su célebre reflexión sobre la forma del ensayo ${ }^{67}$.

${ }^{66}$ Cirilo Flórez, a quien pertenecen las reflexiones de marras, alude a los términos con los que G eorg Simmel caracterizó estas dos vías: la cultura subjetiva y la cultura objetiva. Flórez M iguel, Cirilo: M undo técnico y humanismo. D iscurso de apertura del curso académico 19941995. U niversidad de Salamanca, Salamanca, 1994, p. 18.

${ }^{67}$ Adorno, Walter: "El ensayo como forma". En: Notas de literatura. Ariel, Barcelona, 1962. 
D e conformidad con la vía ética de la modernidad, hubo una manifiesta tendencia a establecer vínculos entre los rasgos formales de una clase de textos y los val ores moral es implícitos, codificadores de dicha clase. Para A renas C ruz: "Las clases de textos del Renacimiento se distinguían unas de otras por la manera en que expresaban la experiencia humana a través de una forma identificable que clarificara o descubriera determinados valores". Los estudiosos de la poética, durante el Renacimiento, verían el concepto de clase de textos menos como una codificación de reglas específicas para una composición que como un gran sistema epistemológico, una manera de mirar einterpretar el mundo y expresar dicha visión de forma más coherente. Es la codificación formal de un valor moral lo que enfatiza la inclusión y la experimentación en la actividad artística renacentista, pues se admitía la cooperación de rasgos procedentes de clases diferentes con el fin de subrayar la capacidad de la literatura para comprometer al hombre en una acción moral ${ }^{68}$. Esta interpretación de la forma y la proyección moral de cierta clase de textos sobrepasa el Renacimiento y puede funcionar con validez en otras coordenadas espacio-temporales, a fin de dar a comprender el uso privilegiado de ciertas formas verbales de comunicación literaria, que expresan las estructuras cosmovisionarias a las que pertenecen.

\section{CONSIDERACIONES FINALES}

Al principio de este trabajo, con el propósito de despejar el problema del género ensayístico, tuvimosque recurrir a una distinción entre las poéticas esencialistas y las condicionalistas, debiendo optar por éstas últimas, en razón de que se ajustaban mejor al examen de un género de la modernidad renacentista y no previsto por la poética clásica ${ }^{69}$. Las poéticas condicionalistas plantean la propiedad literaria de los textos en relación con los niveles contextuales y no contextuales. D e manera que el valor literario-poético dependerá de la convención de un uso de natural eza social marcada por una comunidad cultural. Pero no se agotaría al lí la sanción de la propiedad estética del discurso ensayístico, es decir, en el nivel contextual. Si constituye un género susceptible de incluirse dentro de la creación poética, lo es porqueel poder intuitivo lo condiciona a enfrentar

${ }^{68}$ Arenas C ruz, M aría E.: 0 p. cit., p. 78.

${ }^{69} \mathrm{En}$ el Renacimiento se restaura la tesis de que "el verdadero objeto de la literatura es la imitación de la vida y de la naturaleza, haciendo de la mimesis la condición básica de lo poético hasta el siglo XV III". Por fuerza, ello provoca las distinciones entre las materias literarias (acciones humanas y cosas de la naturaleza) y las científicas o filosóficas. Arenas C ruz, M aría Elena: O p. cit., p. 103. 
la vida y el mundo con el mismo gesto que la obra artística, aun cuando su pretensión última no sea la imitación humana y extrahumana - la 'mimesis'- . La escrupulosa utilización del lenguaje, entonces, no sería el único rasgo definitorio de la propiedad literaria. Lukács descubrió que lo definitorio del género estaba en la articulación establecida entre las facetas concretas de la realidad y las problemáticas esenciales del ser ${ }^{70}$. La primera condición del arte consiste en el evar a la categoría de universal las elementales real idades de la vida, del hombre y su destino, en tal sentido, el ensayo se sujeta a un acto creador artístico al reconocer tales realidades, las que desentraña mediante la fuerza de la intuición. Pero no va más allá de este punto: "El ensayo es un juicio, pero lo esencial en él, lo que decide su valor, no es la sentencia (como en el sistema), sino el proceso mismo de juzgar"71.

Lukács decía que la ciencia obra sobre nosotros por sus contenidos y el arte por sus formas ${ }^{72}$, en consecuencia, podría argüirse que el discurso ensayístico logra situarse en la equidistancia de la forma y el contenido. El carácter bifronte del discurso ensayístico se revela, por una parte, en el plano reflexivo y el pensamiento crítico y, por otra, en la importancia conferida a la presentación artística del pensamiento. Pero la idea de la forma, en este caso, no debeentenderse nada más que como una categoría posible de evaluarse. Se precisa poner en evidencia "Ios princi pios básicos que separan las formas unas de otras"73. La estructura argumentativa del ensayo constituye la bisagra que reúne el ordenamiento más o menos sistemático del pensamiento, por lo que se acerca al discurso teorético, pero la preocupación por la 'dispositio' y la 'elocutio' de las estructuraciones retóricas lo proyecta hacia una noción artística. Comparte con el lenguaje de la ciencia el hecho de no crear mundos ficcionales, empero se distancia, merced a su libertad expositiva. Por eso, en su denodado afán de provocar el placer estético -a un tiempo individual y participativo- por medio de la palabra, el ensayo se sitúa entre los géneros de creación poética y los géneros retóricos. Asimismo, podemos decir que el género ensayístico está profundamente imbricado, en su emergencia, con la afirmación de la individualidad

${ }^{70}$ Lukács, G eorg: "Sobre la esencia y forma del ensayo (C arta a Leo Popper)", p. 38.

${ }^{71}$ bidem.

${ }^{72}$ bidem, p. 17.

${ }^{73 " N}$ o se trata de finura y de profundidad; éstas son categorías valorativas y, por lo tanto, sólo tienen validez dentro de la forma; se trata de los principios básicos que separan las formas unas de otras; se trata del material con el que todo está construido, se trata del punto de vista, de la concepción del mundo que da unidad a todo. Para ser breve: si se compararan las distintas formas de la poesía con la luz solar refractada por el prisma, los escritos de los ensayistas serían la radiación ultravioleta". Lukács, G eorg: "Sobre la esencia y forma del ensayo (C arta a Leo Popper)", p. 23. 
renacentista. Sin embargo, los rasgos constitutivos que se le reconocen: subjetivismo, actitud dialógica, discursividad, no pertenecen exclusivamente al Renacimiento, sino que se convierten en principios constructivos permanentes del género.

\section{BIBLIO GRAFIA}

Adorno, Walter. 1962. "El ensayo como forma". En: N otas deliteratura, Ariel, Barcelona. Alvarado Jiménez, Ramón. 1991. "Géneros y estrategias del discurso". En: Versión, octubre. Altamirano, Carlos, Sarlo, Beatriz. 1980. Conceptos de sociología literaria. CEAL, Buenos Aires.

Arenas Cruz, M aría Elena. 1997. Hacia una teoría general del ensayo. Construcción del texto ensayístico. Ediciones de la Universidad de C astilla-La M ancha, Cuenca.

Auerbach, Erich. 1950. M imesis: la representación dela realidad en la literatura occidental.

Trad. de I. Villanueva y E. Imaz. Fondo de Cultura Económica, M éxico.

Bajtín, M ijaíl, M . 1986. Problemas de la poética de D ostoievski. Trad. Tatiana Bubnova. Fondo de Cultura Económica, M éxico.

Barthes, Roland. 1974. Investigaciones retóricas I : La antigua retórica, Trad. Beatriz D orriots. Tiempo Contemporáneo, Buenos Aires.

Beltrán Almería, Luis. 1998. "El debate sobre la naturaleza estética de la retórica". En: Albaladejo, Tomás, Del Río, Emilio, Caballero, José Antonio (eds.): Quintiliano: H istoria y actualidad dela retórica. Instituto deEstudios Riojanos, Logroño, C alhorra: Ayuntamiento, vol. II.

Benjamin, Walter. 1986. Sobre el programa de la filosofía futura. Planeta-Agostini, Barcelona. Bousoño, Carlos. 1981. Epocas literarias y evolución; Edad M edia, Romanticismo, Epoca Contemporánea. Gredos, M adrid, t. I.

Dijk, Teun A. van. 1987. "La pragmática de la comunicación literaria". En: Dijk, Teun A. van y otros: Pragmática de la comunicación literaria. Arcos/Libros, M adrid.

Ducrot, O swald, Todorov, Tzvetan. 1974. Diccionario enciclopédico de las ciencias del Ienguaje Trad. de Enrique Pezzoni. Siglo XXI, Buenos Aires.

Eagleton, Terry. 1988. U na introducción a la teoría literaria. Trad. de oséEsteban Caldrón. 1 a ed. Fondo de Cultura Económica, M éxico.

Flórez M iguel, Cirilo. 1994. M undo técnico y humanismo. Discurso de apertura del curso académico 1994-1995. Universidad de Salamanca, Salamanca.

Frye, N orthorp. 1975. Anatomía de la crítica. Vers. castellana de Edison Simons. M onte Avila Editores, Caracas.

García Berrio, Antonio, H uerta C alvo, Javier. 1995. L os géner os literarios: sistema e historia (U na introducción). Cátedra, M adrid.

Genette, Gerard. 1988. "'Géneros', 'tipos', 'modos'". En: Garrido Gallardo, M iguel (comp.): Teoría de los géneros literarios. Arcos/Libros, M adrid.

- - - - - . 1993. Ficción o dicción. Trad. de Carlos M anzano. Barcelona, Lumen.

Gomes, M iguel. 1999. Los géneros literarios en H ispanoamérica: Teoría ehistoria. EU N SA, $\mathrm{N}$ avarra.

Gómez M artínez, J oséL uis. 1981. Teoría del ensayo. Universidad de Salamanca, Salamanca. Guillén, Claudio. 1985. Entre lo uno y lo diverso. Introducción a la literatura comparada. Crítica, Barcelona. 
Gurevich, Aarón. 1997. Los orígenes del individualismo europeo. Trad. de M aría García Barris. Crítica, Barcelona.

H ernadi, Paul. 1978. Teoría de los géneros literarios. Antoni Bosch Editor, Barcelona.

$\mathrm{H}$ auser, Arnold. 1983. H istoria social dela literatura y del arte. Trad. A. Tovar y F.P. Varas

Reyes. Labor/Punto O mega, Barcelona, t. 1.

Jakobson, Roman. 1981. Ensayos de lingüística general. Seix Barral, Barcelona.

Lázaro Carreter, Fernando. 1979. "Sobre el género literario". En: Estudios de poética.

Taurus, M adrid.

Lázaro Carreter, Fernando. 1980. "Lenguaje y generaciones”. En: Estudios de lingüística.

Crítica, Barcelona.

Lukács, Georg. 1966. Estética, I. La peculiaridad de lo estético. Trad. M anuel Sacristán. Grijalbo, Barcelona.

- - - - - . 1985. "Sobre la esencia y forma del ensayo (Carta a Leo Popper)". En:

Lukács, G eorg: Teoría de la novela. Trad. M anuel Sacristán. G rijalbo, M éxico.

M arichal, Juan. 1984. Teoría e historia del ensayi smo hispánico. M adrid, Alianza.

M artínez, José Luis. 1958. "Introducción”. En: El ensayo mexicano moderno. Fondo de Cultura Económica, M éxico.

N uez, Antonio dela. 1965. "Antiguosy nuevos métodos de penetración del ensayo". En: Anuario de Filología, Caracas.

N úñez, Estuardo. 1965. "Proceso y teoría del ensayo". En: Revista H ispánica M oderna, a. $X X X I, N \cong 1-4$, oct.

M ontaigne, M ichel de. 1948. Ensayos. Trad. C onstantino Román y Zalamera. El Ateneo, Buenos Aires, t. II.

Rey de Guido, Clara. 1985. Contribuciones al estudio del ensayo en H ispanoamérica. Biblioteca de la Academia $\mathrm{N}$ acional de $\mathrm{H}$ istoria, Caracas.

Reyes, Alfonso. 1961. O bras completas. M éxico, Fondo de Cultura Económica, t. XIII.

Río, Angel del, Bernadete, M. E. 1946. El concepto contemporáneo de España. Antología de ensayos (1895-1931). Losada, Buenos Aires.

Ryan, M arieL aure. 1988. "H acia una teoría de la competencia genérica". En: Garrido Gallardo, M iguel (comp.) Teoría de los géneros literarios. Arcos/Libros, M adrid.

Sáenz H ayes, Ricardo. 1939. M iguel de M ontaigne (1533-1592). Espasa-Calpe, Buenos Aires.

Segre, Cesare. 1985. Principios de análisis del texto. Trad. M aría Pardo de Santayana. Crítica, Barcelona.

Staiger, Emil. 1966. Conceptos fundamentales de poética. Estudio preliminar y vers. esp. Jaime Ferreiro. Rialp, M adrid.

Tinianov, J. 1968. "Sobre la evolución literaria”. En: Todorov, Tzvetan: Teoría de la lite ratura de los formalistas rusos; antología preparada y presentada por Tzvetan Todorov. Trad. de Ana M aría N ethol. Signos, Buenos Aires.

Todorov, Tzvetan. 1972. "Los géneros literarios". En: Introducción a la literatura fantástica. Trad. de Silvia D elpy. Tiempo Contemporáneo, Buenos Aires.

- - - - - . 1996. Los géneros del discurso. Trad. Jorge Romero León. 1ạ ed., M onte Avila Editores, Caracas.

Vitier, M edardo. 1945. D el ensayo americano, Fondo de Cultura Económica, M éxico.

Wellek, René, Warren, Austin. 1966. Teoría literaria. Ver. esp. José M. Gimeno. 4aㅡ ed., Gredos, M adrid.

W illiams, Raymond. 1980. M arxismo y literatura. Trad. Pablo D i M asso. Península, Barcelona. 